\title{
Wonderful things
}

\author{
A date with the past.
}

$\mathrm{H}$ oward drifted back into consciousness. For a few moments he confused the steady wheezing of the ventilator, pumped by one of Lord C_'s own servants, with the rhythmic beat of the steam hammers on the dig in France.

The medics were muttering. As he drifted in and out of consciousness he heard that idiotic phrase, 'The Curse of the Presidents'. Superstitious idiots. The hospital room faded as his struggling brain took him back to the moment when they broke through.

It was the first time he'd been to Europe. For many years after the Collapse, it had been pretty much impossible to visit from the USA. Even now, the stone-age European peasants - all that remained of their great civilization - regarded foreigners with suspicion. But when Lord C_ arranged the dig, the locals in Aube realized that good dollars in the hand were far better than worrying about these strange people with their monstrous, hissing machines.

As Howard watched the excavation engine creep slowly into place, he could understand the fear that the advanced technology of the USA inspired. Yet even they had lost much knowledge in the Collapse. It was what drove him to work 18-hour days on the site. If only they could discover more of the pre-Collapse science, find out how the fabled machinery of the time had worked. But for now they had the solid, reliable monsters of steam to do their bidding, giving US engineers an advantage over every civilization in the known world.

Minutes to go now before they broke through. Just after dawn, a boiler had burst,

\section{$\rightarrow$ NATURE.COM}

Follow Futures: y @NatureFutures f go.nature.com/ mtoodm sending scalding superheated steam spraying across the French workers who queued every morning for the chance to help out on the site, to earn real money. Three killed and another dozen horribly injured. The locals seemed inured to suffering. That was the first time he'd heard about the Curse of the Presidents. His local supervisor, Maxine, had explained it in her broken English.

“They're superstitious, boss. Don't pay any attentions. This place... they think their presidents - they were like the kings they had back then - are buried here. With their treasure. And if anyone breaks in, they suffer the curse. Die horribly. But really they are only saying this because they know it's impossible. For years they've tried to get to the treasure - and no one has ever got in." Howard nodded. The French would think it was about treasure. They probably expected to find golden statues and fancy tombs down under the thick concrete walls that sealed the site. But he knew better. This was no burial place of ancient presidents, it had to be where they'd stored their secrets. Their science and technology. There was a treasure house, for sure, but not the kind of thing the poor, ignorant locals imagined.

The excavation engine's hooter gave off a dramatic blast. Howard smiled at Maxine. "They're close. We're nearly in."

He scrambled down the carefully excavated incline. The blast sounded again. Howard looked back at Maxine, who was still at the top of the slope. Too scared to come closer. One of the US engineers was crouched by the monstrous teeth of the engine's main drill. All around were the remains of reinforced concrete, littering the excavation like rust-stained confetti.

Abena, the engineer, tapped the wall straight in front of the bit. "We're there, chief. It's hollow behind. All it's going to take is one blow and we're through."
Howard's smile turned into a broad grin. "Time to make history, Abena." She handed him a chisel and a hammer. The daguerreotypers and newsgatherers crowded round to catch the moment. Howard turned to face his audience. "This is a great moment for the USA. We have come so far already, but with the technology we will discover inside this repository, we can regain the abilities our ancestors had before the Collapse. The time has come."

Slowly, deliberately for the camera lucida, Howard placed the chisel against the wall and swung the hammer back, bringing it crashing into contact. A sheet of the thin concrete about two hand spans in width fell away, leaving a dark void beyond. Howard gestured eagerly behind him and Abena handed him a lantern. He held it to the hole, peering in above the lantern's chimney.

"Can you see anything?" Abena hissed, pushing up behind him, trying to get a glimpse of the opening.

Howard nodded. "Yes," he said, "wonderful things."

He had seen the shining metal containers, rust-free after so many years. Row, after row of them. Thousands upon thousands, like a buried army of knowledge.

Howard stirred in his bed. He knew the burns were getting worse. He couldn't last much longer. He was dying. And for what? Because when they had opened those glittering containers, all they had found was more concrete. And inside that, industrial garbage. Gloves, protective clothing, wrecked equipment. Nothing of value. Even before the illness had struck, it was as if his life's work had been wasted.

When he had heard about the total destruction of America and the devastation in Europe as a boy, he had known he was the one to bring back the knowledge, to make the United States of Africa what it once was. But it was not to be. Others were ill too. Three had died already. The Curse of the Presidents, it seemed, didn't care whether or not you believed.

BRIAN CLEGG (www.brianclegg.net) is a popular-science author whose books include Dice World, Build Your Own Time Machine and A Brief History of Infinity. 